\title{
Birth of the Open University
}

by our Education Correspondent

THE Open University, after a long and complicated gestation period, will next week see the light of day. It remains to be seen whether the project will be stillborn, or whether it will reach maturity, but it is nevertheless something of a triumph for its supporters that the plans have matured this far. Conceived by Mr Harold Wilson in 1963, and steered through its development by Miss Jennie Lee, the Open University is a bold and ambitious plan to make higher education available to a large number of people who have been denied the opportunity of going to a traditional university. Its potential impact on educational development can be judged in part by the fact that when the first broadcasts are transmitted on the radio network and television channels next week, nearly 25,000 students will be listening in. This one university will therefore account for nearly a third of the total number of students in first year courses at British universities.

But the road to the formal opening next week has not been an easy one, and perhaps the university's largest headache has come during the past few months. After the Conservative government gave the official go-ahead for the project last August, the university offered places to 25,000 of the 42,000 applicants. But by November it was clear that some 20 per cent of the successful candidates had already decided that they did not want to go ahead with their studies-and had not paid their initial $£ 10$ enrolment fee. Although the Open University maintains that such a large falling in interest among the students is not too alarming, there is no doubt that it is something of a setback. It also seems to have caught the university's planners by surprise because the reserve list was too small to fill all the available places and some re-selection had to be done.

But in many ways, the so-called dropout rate is only one part of the university's worries, and it will even be something of a surprise if more than half the students who register stay the course. The studies will not be easy. To get a degree, students must build up a series of credits-six credits will be required for a BA degree, and eight for a degree with honours. Each credit will be awarded for successful completion of a one-year part time course, and it is expected that no more than two courses will be taken in each year. Tuition will consist of a system of correspondence courses, television and radio lectures, and tutorials conducted on a regional basis. Students will also have to spend two weeks each year at a summer school. With these demands on a student's time, a strong commitment will be needed to qualify, and the 20 per cent drop-out rate which has been tentatively suggested for the university is very much an unrealistic estimation.

To the delight of the Open University's many sceptics, it is already clear that the original intention in the back of $\mathrm{Mr}$ Harold Wilson's mind will not be fulfilled. Mr Wilson clearly envisaged the university as a vehicle for enabling manual workers to have an opportunity of taking a degree, but applicants to the university turned out to be almost as overwhelmingly drawn from the middle classes as those to the traditional universities. In spite of preferences being given to candidates from the lower economic groups, the class bias among the students has not been ironed out, but the chances are that if the project is allowed to mature a larger proportion of the applicants to the Open University will come from manual workers.

One of the chief purposes of the Open University is to provide a second bite at the higher education cherry for those students who for one reason or another have missed out on their first opportunity. But it seems likely that this function may also be modified in the near future. The university is at present accepting applications from students aged at least 25: in other words, they will already be in employment, and the Open University will not be vying for candidates with the traditional universities. But the Department of Education and Science, casting around for ways to accommodate the demand for higher education during the next few years, has asked the Open University to look into the possibility of accepting students at the age of 18 . Such a change in policy would have several repercussions-for one thing, the university would find itself attracting many more students who had been rejected by traditional universities, and the other universities would themselves be rather wary of the possibility that the Open University may take away some of their potential candidates. But, paradoxically, taking students at the age of 18 would be a good trump card for the university to play to ensure that it is allowed to carry on.

The Conservative party, which was in Opposition when the plans for the Open University were first aired, has always been sceptical of its chances of success, but when the Conservative government took office in June this year, plans for the institution were already too far advanced to be called off. It now seems that if the university is to be scrapped, the first move will be to cut down on its grant and therefore on the number of students that it will take. The present plans are for a total student population of between 36,000 and 42,000 for 1972 and 1973, but no sanction has yet been given for estimates beyond that date. If, however, the Department of Education and Science sees room in the Open University for relieving the pressures on traditional universities, the future of the university will be more secure.

What, in any case, are the immediate plans of the Open University? Students starting next week will be taking one or two foundation courses in mathematics, science, humanities and understanding society, and next January a foundation course in technology will also be introduced. The six credits needed for a BA degree must include two from successful completion of foundation courses. Most of the broadcasts and correspondence material for this year's foundation courses have already been prepared, and the staff of the university is planning the second year courses. It is intended at present that a student's choice of foundation courses should not limit his choice of second year courses too much. But to take second year courses in science and mathematics, students must have completed foundation courses in those subjects.

As far as postgraduate studies are concerned, there are no plans to offer places for part time students until at least 1973 -at present, there are only a few places available for full-time research students at the Open University's premises at Milton Keynes. But the university intends to introduce updating and postexperience courses to help movement between occupations.

It will not be possible, however, to assess the real contribution of the Open University to higher education in Britain until its first graduates have been produced and have started looking for new jobs. Only then will it be possible to tell whether degrees from the Open University are considered by employers to be on a par with those from traditional universities. Unless this is the case, Open University students will have good cause to complain that their investment in terms of both time and money has been a bad one. 